\title{
The Specifics of the NEETs Population in Bulgaria and Romania
}

\author{
Gabriela Neagu $^{1}$, Vladislava Lendzhova ${ }^{2}$ and Dilyana Keranova ${ }^{2}$ \\ ${ }^{1}$ Research Institute for Quality of Life, Romania \\ ${ }^{2}$ Department of Sociology, South-West University „Neofit Rilski”-Blagoevgrad, Bulgaria
}

\section{Специфики на младите хора извън системите на заетост, образование и обучение (NEETs) в България и Румъния}

\author{
Габриела Неагуํㅜㄹ Владислава Ленджова² и Диляна Керанова ${ }^{2}$ \\ ${ }^{1}$ Изследователски институт за качество на живот, Румъния \\ ${ }^{2}$ Катедра Социология, Югозападен университет Неофит Рилски“-Благоевград, България
}

\begin{abstract}
Authors Note
Gabriela Neagu (iD) https://orcid.org/0000-0001-6655-7256

Vladislava Lendzhova (ii) https://orcid.org/0000-0001-9757-3419

Dilyana Keranova (D) https://orcid.org/0000-0001-6399-9358

The authors have no conflict of interest to disclose.

Correspondence related to this article should be addressed to Vladislava Lendzhova, South-West University “Neofit Rilski”-Blagoevgrad, Bulgaria. Email: vlendzhova@ swu.bg
\end{abstract}

\section{Бележки за авторите}

Габриела Неагу (i) https://orcid.org/0000-0001-6655-7256

Владислава Ленджова (i) https://orcid.org/0000-0001-9757-3419

Диляна Керанова (i) https://orcid.org/0000-0001-6399-9358

Авторите нямат конфликт на интереси. 
Кореспонденцията, свързана с тази статия, да бъде адресирана до Владислава Ленджова, Югозападен университет „Неофит Рилски“-Благоевград, България Еmail: vlendzhova@swu.bg 


\begin{abstract}
NEETs are a social category specific to today's society characterized by increasing inequalities between people, precariousness, and insecurity. At the level of the majority of the population but also among the authorities and specialists (economists, sociologists, psychologists, etc.) the dominant perception is negative on this category of populations often associated with the underclass, dangerous class (Avis, 2014), people getting nowhere (Bynner, Ferri \& Shepherd, 1997) or people at risk (Conrad, 2005). The interest for this category of the population is even higher for Bulgaria and Romania because the share of NEETs is the highest in the EU: 23.8\% in Romania and $20.7 \%$ in Bulgaria (Eurostat database). This paper aims to analyze this category of population to obtain a more realistic image of NEETs, especially in the two Eastern European countries. One of the few positive effects resulting from the accentuation of interest for this category of the population consists in increasing the number of documents (articles, reports, books, etc.) that analyze NEETs. By using alternative research methodologies (literature review) these documents can provide relevant information on NEETs and can provide several clarifications on their situation at the national and European levels.
\end{abstract}

Keywords: NEETs, alternative research methodologies, Bulgaria, Romania

Резюме

Младите хора извън заетостта, образованието и обученията, т.нар. NEETs, са специфична социална категория, чиято характеристика се свързва с увеличаването на неравенствата между индивидите, нестабилността и несигурността в съвременните общества. Доминиращо за тази част от населението е отрицателното възприятие, т.е. голяма част от експертите и специалистите (като икономисти, социолози, психолози и др. ) определят тези младежи като "втора категория хора", "подкласа или опасни за обществото" (Avis, 2014), „индивиди които не стигат до никъде" (Bynner, Ferri \& Shepherd, 1997), "индивиди в риск" (Conrad, 2005). Интересното за тази група, в България и Румъния е, че заемат голям част от населението, защото по данни на Евростат в двете страни има най-висок дял NEETs от целия EC: 23.8\% В Румъния и 20.7\% в България (база данни Евростат). Настоящата статия има за цел да анализира тази част от населението, за да се създаде по-реалистична картина/представа за NEETs в двете източно-европейски държави. Един от малкото положителни ефекти, произтичащи от засилването на интереса към тази част от населението се състои в броя на документите (статии, доклади, книги и т.н.), които анализират NEETs. Чрез използваната 
алтернативна изследователска методология (преглед на литературата) тези документи могат да предоставят съответната информация за NEETs, а също така и да пояснят тяхното положение на национално и европейско ниво.

Keywords: NEETs, алтернативна изследователска методология, България, Румъния 


\section{The specifics of the NEETs ${ }^{1}$ population in Bulgaria and Romania}

The understanding of a social problem depends to a very large extent on the existence of certain information, supported by scientific evidence. The statistical databases collected at the national level but also European level as well as the numerous reports represent an important starting point in establishing the existence of the social problem, the way it manifests itself, the implications and duration, etc. The more scientific evidence there is and the higher the level of trust, the greater the chances of identifying and diagnosing the problem, the higher the intervention of the responsible authorities, and the safer solution. NEETs are one of the very serious social problems facing contemporary society, but controversies over who are the young people belonging to this category of the population (socio-demographic, psycho-physical, assessment of the risk of exclusion, etc.) delay its resolution. In this context, meta-analysis has become a useful and accessible tool through which the results of various researches are collected, classified, and evaluated providing a complete, topical, and reliable picture of a social problem. The call for meta-analysis is increasingly common in recent years and because, according to some researchers (Littell et all, 2008) has significantly increased the number of proponents of current evidence-based practice.

The purpose of this article is to analyze the problem of NEETs through the method of metaanalysis that allows the use of information, data, interpretations available in the scientific literature. The results of the analysis should lead us to the answers to the following questions:

$\checkmark$ What are the problems facing young people classified as NEETs with a focus on the situation in Bulgaria and Romania?

$\checkmark$ Are there situations that "escape" established classifications (eg Eurofound classification)?

$\checkmark$ What are the specific (national) and common (European) factors that place a young person in the NEETs category?

The concept of NEETs

The origin of the concept was established in the early 1980s, when the United Kingdom set out to analyze the problems faced by people aged 16-18 in entering the labor market and for which it needed an indicator of the difference from other vulnerable categories. Subsequently, the deadline was taken over, improved by researchers and international organizations. (Quintini \&

\footnotetext{
${ }^{1}$ Young people neither in employment nor in education or training 
Martin, 2006; OECD, 2008; Eurofound, 2012, 2016). At the EU level, the European Commission considers it a key indicator and not only uses it in strategy papers and programs for young people - "Youth in Action", "Europe 2020" - but calls on the Member States and European organizations to develop and to understand this concept.

In the literature, the term NEETs highlights, in particular, the situations of vulnerability in which young people may be (Nudzor \& Finlay, 2017), disadvantaged family environment (Furlong, 2006), lack of interest in civic and political activities (Volonte, 2012); getting nowhere (Bynner, Ferri, \& Shepherd, 1997); at risk (Conrad, 2005); wasted youth, disengaged, disaffected or disappeared young people (DfES, 2007); generation X (Pearce \& Hillman, 1998); status zero (Williamson, 1997); and non-college bound youth (Worthington \& Juntunen, 1997). The analysis of the definitions and classifications of NEETs reveals a very high level of heterogeneity - young people who voluntarily choose not to enter the labor market or in the education and training system belong to the same category as young people who for objective reasons (illness, growth or care of a family member) do not have a job or cannot attend training courses. Some researchers (Fourlong, 2006) believe that this heterogeneity is not sufficiently analyzed. Another relevant aspect is that its indicator and definition refer to a static situation and assume that a young person belongs forever to this unrealistic category: young people are the age category with the highest educational, professional, social mobility. This means that the share of NEETs in society is fluctuating and difficult to predict. Other opinions draw attention to the fact that the period of youth has been extended (in some states up to 34 years), the one that people spend in school has expanded and educational and professional trajectories are no longer linear time.

\section{Method and materials}

\section{Meta-analysis-procedures}

To search for relevant studies, a comprehensive search was performed using 'ANELIS PLUS', in February 2019- March 2020. This browser includes many databases such as ERIC, Sage, Tylor, SCIENCE DIRECT, etc. To search for potential references, the term 'NEETs' was combined each time with the following terms:" young people"," unemployed"," young people without occupation" etc. but also terms in French such as "Jeune" (Jun), "Jeunes chômeurs (jun shumer)", "Jeunes hors/ du système d'éducation et deformation" to have access to journals published in databases such as "young', "rural area", "unemployment" "Jeune", "to gain access to French databases such as Persee and Cairn. 
In total, 79 articles were identified by these keywords, but some of them, after a careful reading, were excluded because they did not meet the criteria established by the research methodology. Selection of studies

To select relevant studies for this review, a study had to conform to the following criteria:

- articles published between 2010-2020

- the possibility of full and free access to the article

- to be articles published in scientific journals

- address the topic of NEETs

- to present the situation of NEETs only at the level of European countries or problems specific to European states on this subject

-include empirical research.

In the analysis, we also included the EEA countries because they have a collaboration and cooperation relationship with all EU countries but also the UK which at the time of the analysis is still a member of the EU. There are situations in which researchers from EU member states have collaborated in the creation of articles with colleagues outside the EU station (researchers from Turkey, for example) but because the content of the article analyzes a situation in the EU then we considered that the article can be included in the research.

\section{Figure 1}

The study selection process
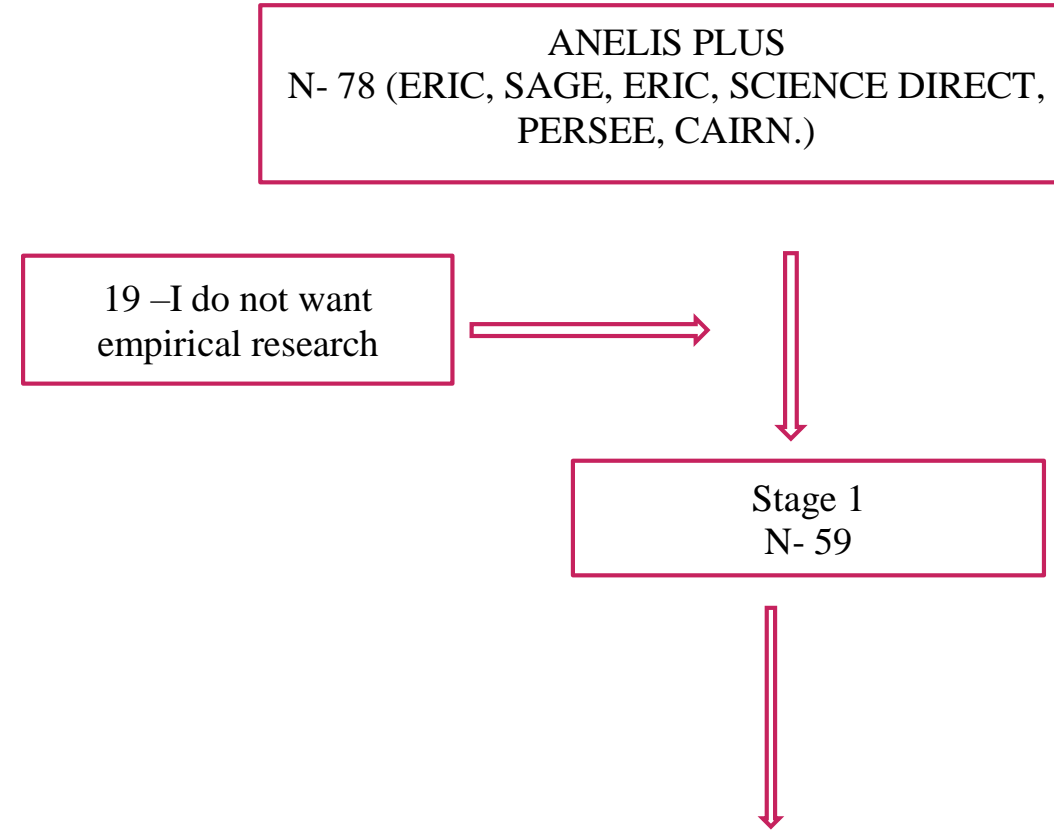

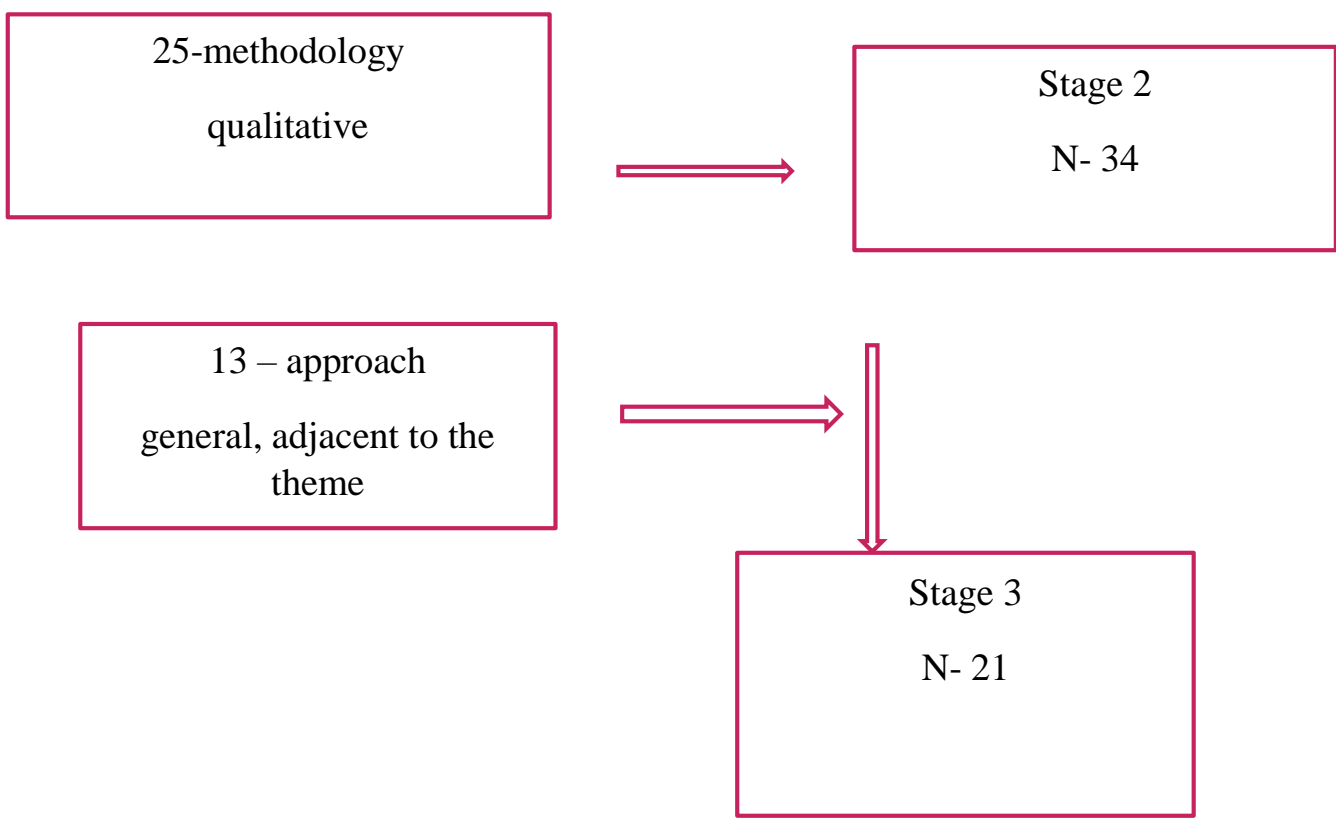

Method

A review study was set up to present a complete and recent overview of empirical studies published in the last 10 years. A first finding is that all selected studies have as a starting point the proposed classification of Eurofound $(2012,2016)$ with the five categories of NEETs: unemployed, unavailable, young people with low levels of school and vocational training, opportunists, and volunteers.

Results

Some articles analyze each of these categories either at the national or comparative level at the European level while other articles focus on a certain category (discouraged or young people with different diseases). Several authors adopt the Eurofound classification without referring to the controversies concerning it while other authors are critical of this classification and bring arguments from their research. Some articles use the quantitative methodology and work with nationally representative samples while others cannot extrapolate the results obtained because only availability samples.

\section{Table 1}

Research tools and number of subjects

\begin{tabular}{|l|l|l|l|l|}
\hline & References & Country & $\mathrm{N}$ & Research tool name \\
\hline $\mathbf{1}$ & S. Alfieri et all., (2015) & IT & 8112 & Youth report \\
\hline
\end{tabular}




\begin{tabular}{|c|c|c|c|c|}
\hline & References & Country & $\mathrm{N}$ & Research tool name (cont.) \\
\hline 2 & M.Vancea et. all., (2018) & ES & 1826 & - \\
\hline 3 & N. Papadakis et all., (2015) & GR & 3459 & $\begin{array}{l}\text { "Absentees' Barometer: the Neets", the } \\
\text { Neets }\end{array}$ \\
\hline 4 & S. Robert et all.,(2019) & FR & 976 & PRESALE \\
\hline 5 & D.Nestić et all.(2018) & HR & - & Household Budget Survey (HBS) \\
\hline 6 & E.V.Bania, et all.,(2019) & NO & 3987 & $\begin{array}{l}\text { Norwegian Arctic Adolescent Health Study } \\
\text { (NAASH) }\end{array}$ \\
\hline 7 & F. E. Caroleo et all (2016) & $\begin{array}{l}\text { IT and } \\
\text { ES }\end{array}$ & & EU-SILC \\
\hline 8 & S. Sacziska-Sokol (2018) & $\mathrm{PO}$ & 300 & - \\
\hline 9 & C.V.Zuccotti, et all., (2018) & UK & 50000 & $\begin{array}{l}\text { Understanding Society -the UK Household } \\
\text { Longitudinal Study (UKHLS) }\end{array}$ \\
\hline 10 & N.Papadakis et all.,(2015) & GR & 3459 & Barometer of Absents: the NEETs \\
\hline 11 & A.Bonanomi et all., (2017) & IT & 1858 & Like Youth \\
\hline 12 & J. Bacher et all.(2017) & AT & 32728 & Austrian Labour Force Survey \\
\hline 13 & R.Stoilova, E.Dimitrova (2017) & BG & 1500 & Schools Leavers Survey \\
\hline 14 & T.H. Stea et all(2019) & NO & 384 & HELLAS Young Study \\
\hline 15 & Z. Bilgen Susanli (2016) & TK & 738386 & Household Labour Force Survey (HLFS) \\
\hline 16 & Santa Tamas (2016) & $\mathrm{HU}$ & 1951 & CSO"s census \\
\hline 17 & M. Symionaki et all (2015) & GR & - & EU-LSF \\
\hline 18 & M.Nordermark et all.(2015) & SE & - & ESS \\
\hline 19 & Kicheva (2017) & BG & 210 & - \\
\hline 20 & L.Tomczyk et all. (2018) & $\begin{array}{l}\text { SK, } \\
\text { PO, } \\
\text { EE }\end{array}$ & 300 & $\begin{array}{l}\text { Cornell Critical Thinking } \\
\text { Test Series } \\
\text { IDEA Questionnaire, Need for Cognition } \\
\text { Scale, } \\
\text { T.I.P }\end{array}$ \\
\hline 21 & S.O.Ose et all., (2017) & NO & 586 & - \\
\hline
\end{tabular}

After applying the selection criteria, 21 studies were selected for this review. Table 1 presents an overview of the selected studies that investigated different categories of NEETs, the number 
of subjects, and the research tools used. A first observation is that we have two papers describing the situation in Bulgaria but we did not find any study to refer to the situation in Romania.

\section{Conclusions}

First of all, the results of our analysis show that the NEETs population is a complex one but, especially in rural areas, tends to be often reduced to the issue of youth unemployment. It is very important to consider all situations of vulnerability in which young people can be. The increase of the efficiency of the public policy measures oriented towards NEETs can be achieved only in the conditions in which not only the national specificity is taken into account, but also the specificity of this category of the population but especially the specificity of each NEETs sub-category. The mapping of the policy documents, which have been focusing on NEETs shows that it has become a significant policy concern. The overarching aim of these policy initiatives is to invest human and financial resources in guaranteeing equal access and high-quality education to pupils from different communities, through for example the exemption of vulnerable groups from tuition fees for education in university. At the same time, it is clear that in the implementation of policies there are still many shortcomings, such as high centralization, low levels of education, and high early school leaving rates.

\section{References}

Avis, J. (2014). Comfort radicalism and NEETs: a conservative praxis. International Studies in Sociology of Education, 24(3), 272-289. https://doi.org/10.1080/09620214.2014.943030

Bynner, J., Ferri, E., \& Shepherd, P. (Eds.). (1997). Twenty-something in the 1990s: Getting on, getting by, getting nowhere. Ashgate.

Conrad, D. (2005). Rethinking 'at-risk in drama education: beyond prescribed roles. Res.

Drama Education. J Applied Theatre Performance, 10(1), 27-

41. https://doi.org/10.1080/13569780500053114

Eurofound. (2012). NEETs - Young people not in employment, education or training:

Characteristics, costs and policy responses in Europe. Publications Office of the European Union https://www.eurofound.europa.eu/publications/report/2012/labourmarket-social-policies/neets-young-people-not-in-employment-education-or-trainingcharacteristics-costs-and-policy 
Eurofound. (2016). Exploring the diversity of NEETs. Publications Office of the European Union https://www.eurofound.europa.eu/bg/publications/report/2016/labour-marketsocial-policies/exploring-the-diversity-of-neets

Furlong, A., \& Cartmel, F. (1997). Young people and social change: Individualisation and risk in late modernity. UK: Open University Press.

Furlong, A. (2006). Not every NEET solution: representing problematic labor market transition in early school leavers. Work, Employment and Society, 20(3), 353-369. https://doi.org/10.1177/0950017006067001

Gervais, M. (2006). Exploring moral values with young adolescents through process drama. International Journal of Education and the Arts, 7(2), 1-34.

Littell, J. H., Corcoran, J., \& Pillai, V. (2008). Systematic reviews and meta-analysis. Oxford University Press

Nudzor, H. (2010). Depicting young people by what they are not: conceptualization and usage of NEET as a deficit label. Educational Futures, 2(2), 12-25.

OECD. (2007). Working Party on the Information Economy ICTs and gender. OECD https://www.oecd.org/sti/38332121.pdf

Pearce, N., and Hillman, J. (1998). Wasted youth: Raising achievement and tackling social exclusion. Institute for Public Policy Research.

Quintini, G., \& Martin, S. (2006). "Starting Well or Losingtheir Way?: The Position of Youth in the Labour Market in OECD Countries". OECD Social, Employment and Migration Working Papers, No. 39, OECD publishing. https://doi.org/10.1787/351848125721

Yates, S., \& Payne, M. (2007). Not so NEET? A critique of the use of 'NEET' in setting targets for interventions with young people. Journal of Youth Studies, 9(3), 329-344. https://doi.org/10.1080/13676260600805671

Volonte, L. (2012). The young generation sacrificed: social, economic, and political implications of the financial crisis. Committee on Social Affairs, Health, and Sustainable Development. https://pace.coe.int/en/files/18739

Williamson, H. (1997). Status zero youth and the 'underclass': Some considerations. In R. McDonald (Ed.), Youth, the underclass and social exclusion (pp. 211-226). Routledge. 
Worthington, R. L., \& Juntunen, C. L. (1997). The vocational development of non-collegebound youth. The Counselling Psychologist, 25(3)323-363.

https://doi.org/10.1177/0011000097253001 